\title{
PROTECTION AGAINST METHYPRYLON OVERDOSAGE BY CATATOXIC STEROIDS
}

\author{
HANS SELYE, C.C., M.D., PH.D., D.SC., F.R.S.C.*
}

METHYPrYLon (Noludar $\left.{ }^{(}\right)$is a well tolerated hypnotic which rarely causes undesirable side effects at recommended therapeutic dose levels. Recovery has occurred after ingestion of as much as $20 \mathrm{gm}$ although in one case $6 \mathrm{gm}$ proved to be fatal. Little is known about the distribution and metabolism of methyprylon beyond the fact that less than 3 per cent of the orally administered dose appears in the urine unchanged and about 3 per cent is excreted by the kidney as the dehydrogenation product 3,3-diethyl-2,4-dioxo-5-methyltetrahydropyridine. It is noteworthy that although methyprylon has not been demonstrated to cause any blood dyscrasias, an analogous tetrahydropyridine has been implicated as a possible causative factor in agranulocytosis. ${ }^{1}$

It has been shown recently that spironolactone (Aldactone ${ }^{\circledR}$ ) inhibits the anaesthetic and sedative actions of various compounds including methyprylon, ${ }^{2}$ and since this antimineralocorticoid is also endowed with strong catatoxic potency, it was thought of interest to examine the possible protective effect of other catatoxic steroids and related compounds upon the anaesthesia produced in rats by heavy methyprylon overdosage.

Catatoxic steroids are characterized by their ability to protect against the toxic actions of numerous drugs independently of their specific hormonal actions. Thus, the most active catatoxic steroids so far identified are spironolactone, compound sc-11927 (both potent antimineralocorticoids, virtually devoid of true hormonal properties), ethylestrenol, and norbolethone (anabolic steroids having no antimineralocorticoid effects); indeed, comparative studies with more than 200 natural and synthetic steroids have shown that the catatoxic effect manifests itself independently of glucocorticoid, mineralocorticoid, luteoid, virilizing, or feminizing properties. ${ }^{3}$

The broad activity spectrum of the catatoxic steroids is illustrated by the fact that they can induce resistance in rats against such varied types of intoxication as steroid anaesthesia, ${ }^{4}$ pentylenetetrazol convulsions, ${ }^{5}$ the calcinosis elicited by vitamin-D congeners, ${ }^{6-8}$ digitoxin poisoning, ${ }^{,}$the hypnotic action of pentobarbital and methyprylon, ${ }^{2}$ the adrenal necrosis produced by 7,12-dimethylbenz (a) anthracene ${ }^{10}$ and the perforating jejunal ulcers elicited by indomethacin overdosage. ${ }^{11}$ Probably many if not all of these protective effects are due to the induction by catatoxic steroids of hepatic microsomal drug-metabolizing enzymes. ${ }^{10,11}$

Even the strongest pure glucocorticoids such as triamcinolone do not protect against most of the substrates that are inactivated by typical catatoxic steroids, although they can influence barbiturate anaesthesia. Thus, in rats, pretreatment with cortisone or prednisolone diminishes the anaesthetic effect of hexobarbital

- Institut de Médecine et de Chirurgie expérimentales, Université de Montréal.

Canad. Anaesth. Soc. J., vol. 17, no. 2, March 1970 
and increases its degradation by liver slices in vitro. ${ }^{12-14}$ On the other hand, pretreatment with cortisone prolongs phenobarbital anaesthesia in guinea pigs and hexobarbital anaesthesia in mice, but shortens thiopental anaesthesia in rabbits. ${ }^{15}$ Barbital anaesthesia is not significantly influenced by cortisone in rabbits. ${ }^{16}$ Curiously, in 11 of 13 patients who recovered from barbiturate poisoning, sleep was reinduced by subsequent cortisone treatment. ${ }^{17}$ In view of these apparently contradictory findings, we have also included two typical glucocorticoids, prednisolone and triamcinolone, among the steroids whose effect upon methyprylon anaesthesia was to be examined in this series.

\section{METHOD}

One hundred and fifteen female Holtzman rats, with an initial body weight of 100 gm (range 90-110 gm), were maintained on Purina Laboratory Chow and tap water, divided into 11 equal groups and treated as outlined in Table I; only in the control group did we use 15 rats. Methyprylon (Hoffmann-La Roche) was administered at the dose of $20 \mathrm{mg}$ per $100 \mathrm{gm}$ body weight in $0.2 \mathrm{ml}$ of water subcutaneously on the fourth day after initiation of steroid treatment, since it is known that in order to obtain the best prophylactic effect with these compounds, it is important to allow a few days of pretreatment.

The following steroids were tested: ethylestrenol (Organon), sc-11927 (Searle), spironolactone (Searle), norbolethone (Wyeth), oxandrolone (Searle), prednisolone acetate (Roussel), triamcinolone (Lederle), desoxycorticosterone acetate (Ciba), progesterone (Schering), and hydroxydione sodium hemisuccinate (Pfizer). All of these steroids were administered by stomach tube in doses of $10 \mathrm{mg}$ in $1 \mathrm{ml}$ of water twice daily beginning on the first day of the experiment.

The depths of anaesthesia or sedation assessed five hours after methyprylon injection were estimated in terms of an arbitrary scale in which $0=$ no change, $1=$ manifest sluggishness indicative of sedation, $2=$ maintenance of supine position but righting upon pinching the tail and $3=$ deep anaesthesia with loss of righting reflex as outlined elsewhere. ${ }^{2}$ However, for statistical evaluation we recognized only two grades: minor and sometimes dubious degrees of anaes-

TABLE I

\begin{tabular}{clc}
\hline \hline Group & \multicolumn{1}{c}{ Treatment $^{*}$} & Anaesthesia \\
\hline 1 & None & $15 / 15$ \\
2 & Ethylestrenol & $0 / 10 \dagger$ \\
3 & Sc-11927 & $0 / 10 \dagger$ \\
4 & Spironolactone & $0 / 10 \dagger$ \\
5 & Norbolethone & $0 / 10 \dagger$ \\
6 & Oxandrolone & $0 / 10 \dagger$ \\
7 & Prednisolone & $0 / 10 \dagger$ \\
8 & Triamcinolone & $0 / 10 \dagger$ \\
9 & Desoxycorticosterone & $9 / 10 \mathrm{NS}$ \\
10 & Progesterone & $7 / 10 \mathrm{NS}$ \\
11 & Hydroxydione & $8 / 10 \mathrm{NS}$ \\
\hline
\end{tabular}

*In addition to the steroids listed in this column, the rats of all groups were given methyprylon as indicated in the text. The readings were made five hours after methyprylon administration.

tp $<0.005 ; \mathrm{NS}=$ not significant. 
thesia (between " 0 " and " + ", in our scale) were rated as negative, all others as positive. These data were then arranged in a $2 \times 2$ contingency table and the statistical significance computed by the "Exact Probability Test" of Fisher and Yates. ${ }^{18,19}$

\section{RESULTS}

As shown by Table I, all the typical catatoxic steroids, namely ethylestrenol, sc-11927, spironolactone, and norbolethone were highly active in protecting the rat against methyprylon anaesthesia. However, the two glucocorticoids of this series, prednisolone and triamcinolone, were also efficacious in this respect. It is known that prednisolone does possess some catatoxic activity, for example, against indomethacin, ${ }^{20}$ but triamcinolone is a virtually pure glucocorticoid which offers no protection against any of the characteristic substrates of catatoxic steroids tested up to now. It appears therefore that methyprylon overdosage can be counteracted by catatoxic steroids as well as by glucocorticoids, whereas compounds devoid of both these actions, such as desoxycorticosterone, progesterone, and hydroxydione, do not posses this protective effect.

\section{Discussion}

It is noteworthy that in this series the steroids previously found to protect against many other types of intoxication ${ }^{3,7-9}$ are also highly potent in combating methyprylon overdosage. However, two glucocorticoids, prednisolone (which in other tests exhibited nil or only irregular catatoxic potency) and triamcinolone (which appears to be totally devoid of it), were also active in offering protection against methyprylon. The typical catatoxic effect appears to be mediated entirely, or at least predominantly, through the induction of hepatic drug-metabolizing microsomal enzymes, yet certain anaesthetics may be subject also to inactivation by other mechanisms which are under glucocorticoid control. It is known that steroids do exert important direct effects upon the central nervous system. Insomnia is not an uncommon complaint of patients kept on massive doses of glucocorticoids; furthermore, various steroids can produce excitation or even deep anaesthesia, ${ }^{21,22}$ a finding which eventually led to the development of hydroxydione (Viadril ${ }^{\circledR}$ ) for use in clinical anaesthesiology. Such an additional point of attack may also explain the apparently contradictory data obtained on the effect of glucocorticoids upon various barbiturates. ${ }^{12-17}$

The resistance induced by glucocorticoids may depend in part upon the induction of changes in the central nervous system itself, enhanced drug storage in tissues, accelerated elimination, etc., independently of the hepatic microsomal enzyme synthesis characteristic of catatoxic steroids. In any event, it is clear that not all substrates are inactivated by the same type of steroid and that methyprylon overdosage can be combatted both by typical catatoxic and by glucocorticoid compounds.

\section{SUMMARY}

In the rat, deep anaesthesia produced by heavy overdosage with methyprylon can be overcome both by typical catatoxic steroids (ethylestrenol, sc-11927, 
spironolactone, norbolethone, oxandrolone) and by glucocorticoids (prednisolone, triamcinolone). On the other hand, desoxycorticosterone, progesterone, and hydroxydione, which are devoid of glucocorticoid activity and possess little or no catatoxic potency, fail to offer significant protection against methyprylon.

\section{Résumé}

Une anesthésie profonde produite chez le rat par une dose élevée de méthyprylon peut être combattue par les stéroïdes catatoxiques typiques (l'éthylestrénol, le sc-11927, la spironolactone, la norboléthone et l'oxandrolone) et par des glucocorticoïdes (la prednisolone et la triamcinolone). Par contre, la désoxycorticostérone, la progestérone et l'hydroxydione, qui sont dépourvues d'activité glucocorticoïde et qui ne possèdent que peu ou pas de pouvoir catatoxique n'offrent aucune protection significative contre le méthyprylon.

\section{ACKNOWLEDGMENTS}

This work was supported by the Ministère de la santé, Québec, and by the Medical Research Council of Canada (Block Term Grant MT-1829).

The author also wishes to thank the following companies for kindly supplying the compounds used in this experiment: Ciba Co. Ltd. (desoxycorticosterone acetate), G. D. Searle \& Co. (sc-11927, spironolactone and oxandrolone), Hoffmann-La Roche Ltd. (methyprylon), Pfizer Ltd. (hydroxydione sodium hemisuccinate), Lederle Laboratories (triamcinolone), Organon Inc. (ethylestrenol), Schering Corp. (progesterone), and Wyeth Laboratories (norbolethone).

\section{REFERENCES}

1. Sharpless, S. K. Hypnotics and Sedatives. In: Goodman, L. S. \& Gilman, A. The Pharmacological Basis of Therapeutics. 3rd ed. New York: Macmillan (1965), pp. 129-42.

2. Selye, H.; Mécs, I.; \& Savone, L. Inhibition of Anesthetics and Sedative Actions by Spironolactone. Anesthesiology. 31: 261 (1969).

3. SELye, H. Catatoxic Steroids. C.M.A.J. 101: 51 (1969).

4. - Acquired Adaptation to the Anesthetic Effect of Steroid Hormones. J. Immunol. 41: 259 (1941).

5. The Antagonism between Anesthetic Steroid Hormones and Pentamethylenetetrazo] (Metrazol). J. Lab. Clin. Med. 27: 1051 (1942).

6. - Effect of Various Hormones upon the Syndrome of Dihydrotachysterol (AT-10) Intoxication. Acta Endocr. 25: 83 (1957).

7. Selye, H.; Grasso, S.; \& Padmanabhan, N. Protection by Antimineralocorticoid against an Otherwise Fatal Dihydrotachysterol Intoxication. Lancet. $i i: 1351$ (1960).

8. Selye, H.; Tuchweber, B.; \& Jaceme, M. Protection by Various Anabolic Steroids against Dihydrotachysterol Induced Calcinosis and Catabolism. Acta Endocr. 49: 589 (1965).

9. Selye, H.; Krajny, M.; \& Savore, L. Digitoxin Poisoning: Prevention by Spironolactone. Science. 164: 842 (1969).

10. Kovacs, K. \& Somogri, A. Prevention by Spironolactone of 7,12-dimethyl-benz(a)anthracene-induced Adrenal Necrosis. Proc. Soc. Exper. Biol. Med. 131: 1350 (1969).

11. SELYe, H. Prevention of Indomethacin-induced Intestinal Ulcers by Spironolactone and Norbolethone. Canad. J. Physiol Pharmacol. 47: 981 (1969).

12. Remmen, H. Die Verstärkung der Abbaugeschwindigkeit von Evipan durch Glykocorticoide. Arch. exper. Pathol. u. Pharmakol. 233: 184 (1958). 
13. Rupe, B. D.; Bousquet, W. F.; \& MrYA, T. S. Stress Modification of Drug Response. Science. 141: 1186 (1963).

14. Winter, C. A. \& Flataker, L. The Effect of Cortisone, Desoxycorticosterone, Adrenocorticotrophic Hormone and Diphenhydramine upon the Responses of Albino Mice to General Anesthetics. J. Pharmacol. Exper. Therap. 105: 358 (1952).

15. Frommel, E.; von Ledebur, I.; \& Beguin, M. De l'action pseudomorphinique de la cortisone en administration unique et de son effet amphétaminolike en administration répétée. Expérimentation animale. Schweiz. med. Wchnschr. 92: 1265 (1962).

16. KomiYa, A.; Machida, J.; Kosuge, M.; \& Fukushima, K. The Effect of the Administration of Cortisone Acetate on Barbital Anesthesia in Male Rabbits. Gunma J. Med. Sc. 5: 71 (1956).

17. Dhunèr, K. G. \& Nondovist, P. Sleep Reinduced by Cortisone and Glucose in Patients Intoxicated with Barbiturates and Related Drugs. Acta anaesth. scandinav. 1: 55 (1957).

18. Frnney, D. J. The Fisher-Yates Test of Significance in $2 \times 2$ Contingency Tables. Biometrika. 35: 145 (1948).

19. Suegel, S. Nonparametric Statistics for the Behavioral Sciences. New York: McGraw-Hill (1956).

20. SELYE, H. Prevention of Indomethacin-induced Intestinal Ulcers by Various Steroids. Exper. Med. Surg. (In press.)

21. - Anesthetic Effect of Steroid Hormones. Proc. Soc. Exper. Biol. Med. 46: 116

(1941).

22. — The Anesthetic Action of Orally Administered Steroids. Anesth. \& Analg. 22: 105 (1943). 